\title{
Characteristics of Histamine Receptors in Human Cerebral Arteries
}

\author{
Takuji TAKAGI, En-Chow TAN and Shoji SHIBATA*
}

\author{
Department of Neurosurgery, Nagoya City Higashi General Hospital, Nagoya; \\ *Department of Pharmacology, School of Medicine, University of Hawaii, \\ Honolulu, Hawaii, U.S.A.
}

\begin{abstract}
Histamine and 2,2-pyridylethylamine, an $\mathrm{H}_{1}$-receptor agonist, (both $10^{-8}-10^{-3} \mathrm{M}$ ) caused contraction of human cerebral artery preparations in the absence of active tension, while dimaprit, an $\mathrm{H}_{2}$-receptor agonist, caused vasorelaxation. The histamine-induced vasoconstriction was blocked non-competitively by tripelennamine, an $\mathrm{H}_{1}$-receptor antagonist. In the presence of cimetidine, an $\mathrm{H}_{2}$-receptor antagonist, histamine-induced contraction was enhanced. The histamine-induced contraction was not affected by phentolamine or propranolol, but abolished by nifedipine. In prostaglandin $F_{2 \alpha}$-precontracted arteries, histamine and dimaprit caused relaxation, while 2,2-pyridylethylamine had no apparent effect. Histamine-induced relaxation was much greater in the presence than in the absence of an $\mathbf{H}_{1}$-antagonist. The vasorelaxation induced by histamine in the presence of an $\mathbf{H}_{1}$-antagonist was also inhibited by an $\mathrm{H}_{2}$-antagonist. Histamine caused no apparent relaxation in precontracted preparations without endothelium. The present results provide further evidence that histamine causes either vasocontraction or vasodilation in human cerebral arteries, and suggest that vasocontraction and vasorelaxation are due to the activation of $\mathrm{H}_{1}$ - and $\mathrm{H}_{2}$-receptors, respectively. The relaxation induced by histamine may also be related to the endothelium-derived relaxing factors released from endothelial cells.
\end{abstract}

Key words: human cerebral arteries, histamine response, histamine receptors, endothelium

\section{Introduction}

Histamine is synthesized, stored and released at several locations near the cerebral vessels. The vascular responsiveness to histamine of the cerebral blood vessels is still unclear. Histamine acts as a potent cerebral vasodilator in vivo. ${ }^{3,27,29,33,34)}$ In vivo experiments have shown that stimulation of histamine receptors with specific $\mathrm{H}_{1}$ - and $\mathrm{H}_{2}$-receptor agonists causes dilation of pial cerebral arteries. ${ }^{11,12)}$ However, histamine usually causes contraction of the cerebral arteries in different experimental animals, such as the cat, ${ }^{19.20)} \mathrm{dog},{ }^{2.17)}$ goat, ${ }^{31)}$ cow, ${ }^{71}$ and in man. ${ }^{25)}$

Animal experiments have indicated the existence of both $\mathrm{H}_{1}$ (constrictor) and $\mathrm{H}_{2}$ (dilator) histamine receptors in the cerebral vascular system..$^{9,13,31)}$ The response of in vitro human cerebral arteries to

Received December 3, 1992; Accepted February
19,1993 vasoactive agents is often different compared to cerebral arteries from experimental animals. This study investigated the responsiveness to histamine of human cerebral arteries in vitro.

\section{Materials and Methods}

Human cerebral arteries $\left(\mathbf{M}_{\mathbf{2}}\right.$ portions of the middle cerebral arteries) were obtained at autopsy within 8 hours after death from 20 male and female patients, 60-85 years of age, who died from respiratory failure (pneumonia) or cancer of the stomach. The arteries were kept in a cold Krebs-Ringer solution for 30 minutes before arrival in the laboratory. All these patients demonstrated arteriosclerotic changes in most of the vasculature.

Helical strips $(2.5 \mathrm{~cm}$ in length and $2.5 \mathrm{~mm}$ in width) from the cerebral arteries were prepared eliminating as much of the lesions as possible, and mounted vertically in a tissue bath containing $20 \mathrm{ml}$ Krebs-Ringer solution with the composition (mM): 
$\mathrm{NaCl}, 120.3 ; \mathrm{KCl}, 4.8 ; \mathrm{CaCl}_{2}, 1.2 ; \mathrm{MgSO}_{4} .7 \mathrm{H}_{2} \mathrm{O}$, 1.3; $\mathrm{NaHCO}_{3}, 24.2$; and glucose, 5.5. A gas mixture of $95 \% \mathrm{O}_{2}$ and $5 \% \mathrm{CO}_{2}$ was passed through the solution maintained at $37 \pm 1^{\circ} \mathrm{C}, \mathrm{pH} 7.3$. In most experiments, a resting tension of $1 \mathrm{~g}$ was initially applied to the strips and maintained throughout the experiment. The preparations were allowed to equilibrate for 60 minutes in the bath before the experiment commenced. Isometric tension changes were measured by a force-displacement transducer (TB-612T; Nihon Kohden, Tokyo), connected to a minipolygraph (CP-602G; Nihon Kohden).

The following agents were used: histamine dihydrochloride (Katayama Chemical Co., Osaka); $\mathbf{H}_{1}$-agonist, 2,2-pyridylethylamine (2-PEA) (Aldrich Chemical Co., Milwaukee, Wis., U.S.A.); $\mathrm{H}_{2}$-agonist, dimaprit (Fujisawa Co., Osaka); $\mathrm{H}_{1}$-antagonist, tripelennamine (Sigma Chemical Co., St. Louis, Mo., U.S.A.); $\mathrm{H}_{2}$-antagonist, cimetidine (Smith Klein \& French Lab., Philadelphia, Pa., U.S.A.); Ca-antagonist, nifedipine (Bayer Co., Leverkusen, Germany); $\alpha$-adrenoceptor-blocking agent, phentolamine (CibaGeigy Co., Basel, Switzerland); and $\beta$-adrenoceptorblocking agent, propranolol (Sigma Chemical Co.).

Histamine, $\mathrm{H}_{1}$ - or $\mathrm{H}_{2}$-agonists were added to the bath to obtain a cumulative concentration-response curve. Antagonists were added to the bath $20 \mathrm{~min}$ utes before addition of the agonists. The responses to histamine were also examined in cerebral arteries precontracted with $5 \times 10^{-6} \mathrm{M}$ prostaglandin $F_{2 \alpha}$ $\left(\mathrm{PGF}_{2 \alpha}\right)$ (Sigma Chemical Co.). Concentrationresponse curves for histamine were obtained in the absence and presence of antagonists.

Endothelium was removed from some preparations by rubbing the intimal surface with a steel spatula. The procedure was considered successful if relaxation with acetylcholine chloride (Sigma Chemical Co.) was less than $5 \%$ of the control level.

The data are presented as means \pm SE. Statistical analysis used the Student's t-test or analysis of variance followed by Dunett's test. Significant differences between control and test groups were evaluated using $\mathrm{p}<0.05$ as the significance level. The competitive relationship between agonists and antagonists was calculated using the method of Arunlakshana and Schild. ${ }^{4)}$

\section{Results}

\section{Effects of histamine on preparations without ac- tive tension}

Histamine at $10^{-8}-10^{-3} \mathrm{M}$ and 2-PEA at $10^{-8}$ $10^{-3} \mathrm{M}$ both caused concentration-dependent contraction of human cerebral arteries without tone (Fig. 1).

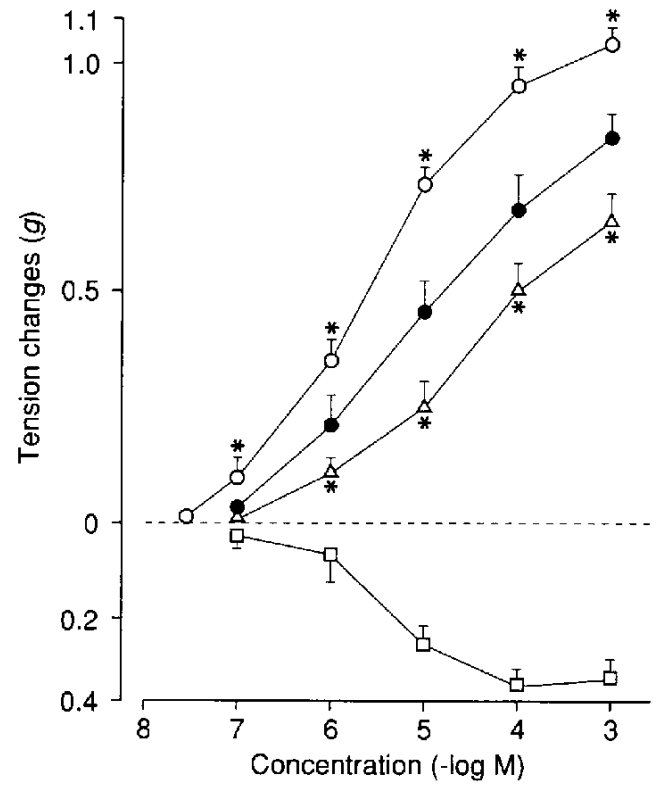

Fig. 1 Effects of histamine with $(0)$ or without $(\bullet)$ cimetidine $\left(10^{-5} \mathrm{M}\right), 2$-PEA $(\triangle)$ and dimaprit ( $\square$ ) on isolated human cerebral arteries in the absence of active tension. Each point represents the mean $\pm \mathrm{SE}$ of six values. ${ }^{*}$ Significantly different $(p<0.05)$ from histamine response.
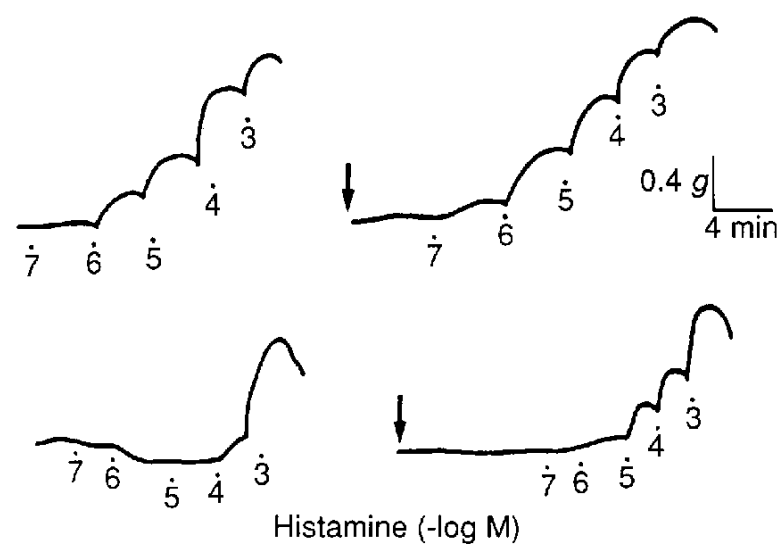

Fig. 2 Representative traces of the response to histamine in isolated human cerebral arteries in the presence (left) or absence (right) of cimetidine $\left(10^{-5} \mathrm{M}\right.$, arrow). upper: Typical response to histamine. lower: Atypical response to histamine.

The contractile effect of histamine was greater than that of 2-PEA. The potency $(50 \%$ effective dose: $\left.E D_{50}\right)$ of histamine also was greater than that of 2PEA. Dimaprit at $10^{-7}-10^{-3} \mathrm{M}$ caused concentra- 
tion-dependent vasorelaxation.

In the presence of cimetidine $\left(10^{-5} \mathrm{M}\right)$, the concentration-response curve for histamine shifted to the greater response side of the control curve with an increase in maximum tension, as shown by Figs. 1 and 2 upper. In two of 10 preparations, histamine at low concentrations $\left(10^{-7}-10^{-5} \mathrm{M}\right)$ caused slight relaxation, while histamine at high concentrations $\left(10^{-4}\right.$ and $\left.10^{-3} \mathrm{M}\right)$ produced contraction. The relaxation was inhibited by cimetidine (Fig. 2 lower). This effect, however, was not observed in the response to 2-PEA.

Tripelennamine at $3 \times 10^{-9}, 10^{-8}$ and $3 \times 10^{-8} \mathrm{M}$ in the presence of cimetidine $\left(10^{-5} \mathrm{M}\right)$ shifted the concentration-response curve for histamine to the lower response side of the control curve without affecting the maximum contraction (Fig. 3). Inhibition due to tripelennamine was not competitive, since the slope of the regression line in Schild plots of the response to histamine was less than unity $(0.78 \pm 0.10)$.

In the presence of cimetidine $\left(10^{-5} \mathrm{M}\right)$, both phentolamine and propranolol (both $10^{-6} \mathrm{M}$ ) did not affect the histamine-induced contraction, $\mathrm{ED}_{50}(\mathrm{M})$ and maximum contraction $(g)$ were: $3.8 \pm 0.2 \times$ $10^{-6}$ and $1.10 \pm 0.2$ for the control; $4.0 \pm 0.3 \times$ $10^{-6}$ and $1.16 \pm 0.2$ for phentolamine; and $4.2 \pm 0.3$ $\times 10^{-6}$ and $1.14 \pm 0.2$ for propranolol $(\mathrm{n}=4)$.

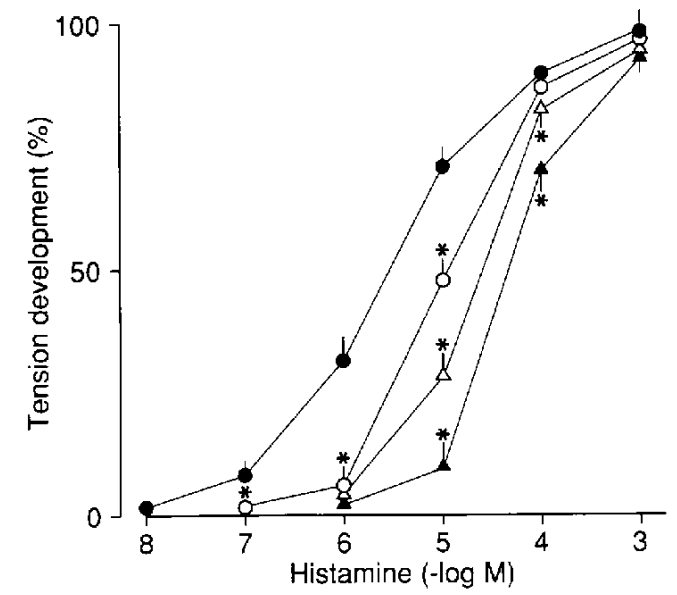

Fig. 3 Inhibitory effect of tripelennamine $(0: 3 \times$ $\left.10^{-9} \mathrm{M}, \triangle: 10^{-8} \mathrm{M}, \Delta: 3 \times 10^{-8} \mathrm{M}\right)$ on contractile responses to histamine in isolated human cerebral arteries in the absence of active tension. Tissues pretreated with cimetidine $\left(10^{-5} \mathrm{M}\right)$. Each point represents the mean \pm SE of seven experiments. Maximum contraction induced by $10^{-3} \mathrm{M}$ histamine is expressed as $100 \%$ of maximum developed tension. *Significantly different $(\mathrm{p}<0.05$ ) from control $(\bullet)$.

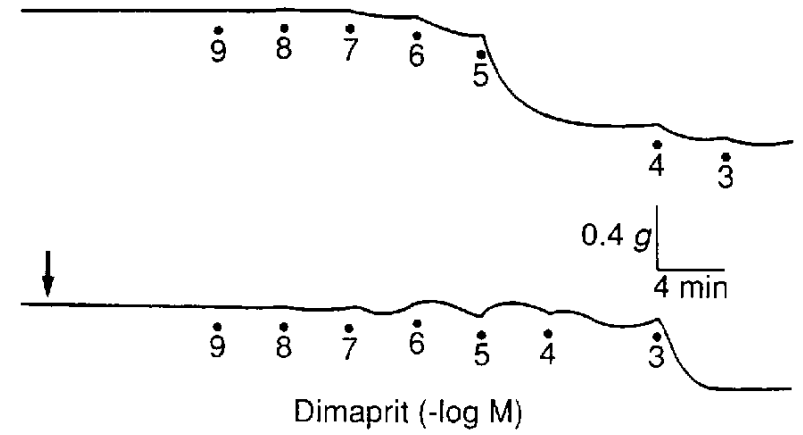

Fig. 4 Representative traces of the inhibitory effect of cimetidine (arrow) on dimaprit-induced relaxation in isolated human cerebral arteries in the absence of active tone.

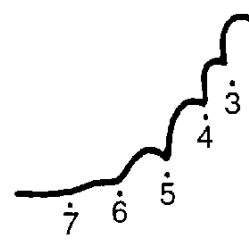

Histamine $(-\log M)$

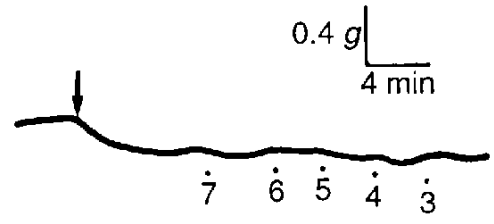

Fig. 5 Representative traces of the inhibitory effect of nifedipine (arrow) on histamine-induced contraction in isolated human cerebral arteries in the presence of cimetidine $\left(10^{-5} \mathrm{M}\right)$.

Dimaprit at $10^{-7}-10^{-4} \mathrm{M}$ induced relaxation in the arteries without tone $(n=3)$, which was almost completely inhibited by pretreatment with cimetidine at $10^{-5} \mathrm{M}$, but at a high concentration $\left(10^{-3} \mathrm{M}\right)$ dimaprit still caused relaxation (Fig. 4).

Nifedipine $\left(10^{-6} \mathrm{M}\right)$ caused the resting tension of arteries to decrease, and subsequent addition of histamine $\left(10^{-7}-10^{-3} \mathrm{M}\right)$ caused no contraction (Fig. 5).

\section{Effect of histamine on preparations with active tension}

In tissues pretreated with $\mathrm{PGF}_{2 \alpha}\left(5 \times 10^{-6} \mathrm{M}\right)$, histamine at low concentrations $\left(10^{-8}-10^{-5} \mathrm{M}\right)$ caused concentration-dependent relaxation, but high concentrations $\left(10^{-4} \mathrm{M}\right)$ caused only slight contraction in the absence of tripelennamine (Fig. 6). 2PEA $\left(10^{-8}-10^{-4} \mathrm{M}\right)$ had no apparent effect in precontracted arteries, while dimaprit $\left(10^{-8}-10^{-4} \mathrm{M}\right)$ caused concentration-dependent relaxation. Histamine $\left(10^{-5} \mathrm{M}\right)$ and dimaprit $\left(10^{-4} \mathrm{M}\right)$ decreased the $\mathrm{PGF}_{2 \alpha}$-induced contraction by $36 \pm 1.1$ and $30 \pm$ 

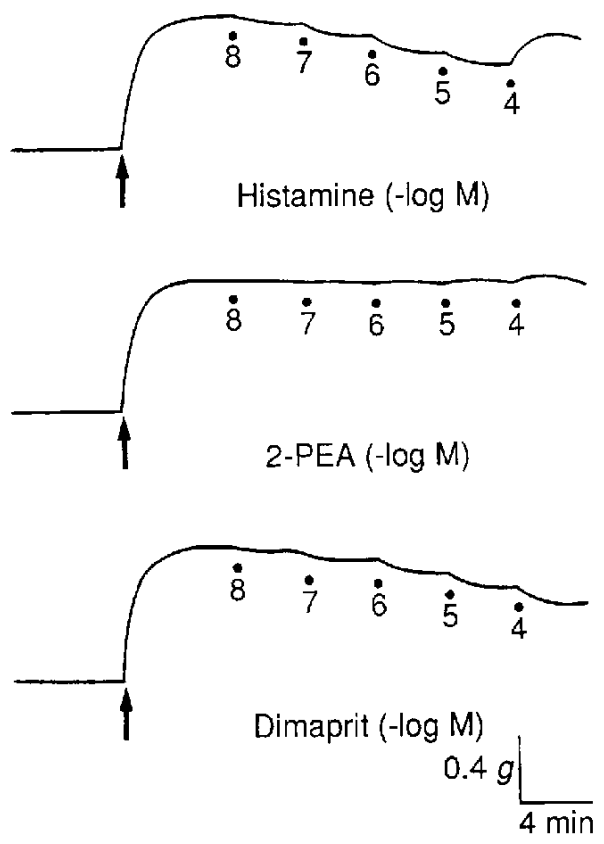

Fig. 6 Representative traces of the response to histamine (upper), 2-PEA (middle) and dimaprit (lower) in cerebral arteries precontracted with $\mathrm{PGF}_{2 \alpha}\left(5 \times 10^{-6} \mathrm{M}\right.$, arrow $)$.

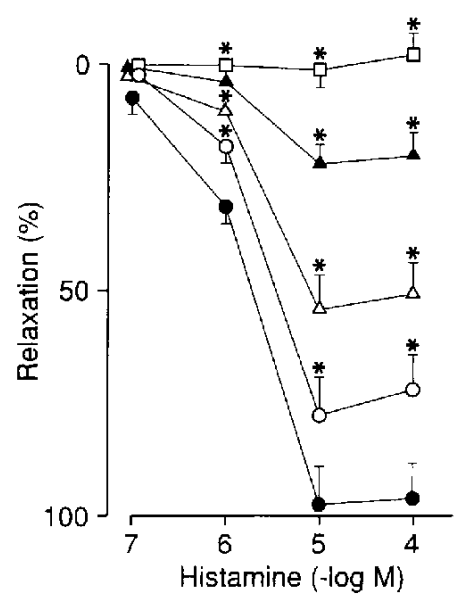

Fig. 7 Inhibitory effect of cimetidine $\left(0: 3 \times 10^{-7} \mathrm{M}\right.$, $\left.\triangle: 10^{-6} \mathrm{M}, \Delta: 3 \times 10^{-6} \mathrm{M}, \square: 10^{-5} \mathrm{M}\right)$ on relaxation response to histamine in cerebral arteries precontracted with $\mathrm{PGF}_{2 \alpha}\left(5 \times 10^{-6}\right.$ M). Each point represents the mean $\pm \mathrm{SE}$ for five experiments. Complete relaxation induced by $10^{-5} \mathrm{M}$ histamine in the presence of tripelennamine $\left(10^{-6} \mathrm{M}\right)$ is expressed as $100 \%$ of maximum relaxation. *Significantly different $(\mathrm{p}<$ $0.05)$ from control $(\bullet)$.
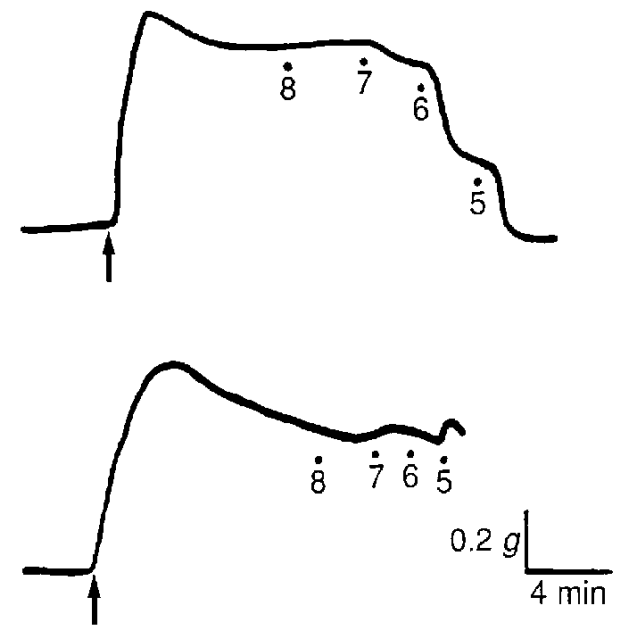

Histamine $(-\log M)$

Fig. 8 Representative traces of histamine-induced relaxation in normal (upper) and rubbed (lower) cerebral arteries precontracted with $\mathrm{PGF}_{2 \alpha}\left(5 \times 10^{-6} \mathrm{M}\right.$, arrow $)$. The tissues were pretreated with tripelennamine $\left(10^{-6} \mathrm{M}\right)$.

$1.4 \% \quad(\mathrm{n}=5)$, respectively. Cimetidine $\left(10^{-5} \mathrm{M}\right)$ completely blocked the relaxation in both cases (data not shown).

Histamine $\left(10^{-7}-10^{-4} \mathrm{M}\right)$ caused much greater relaxation in the presence of tripelennamine $\left(10^{-6} \mathrm{M}\right)$ than in its absence (Fig. 7), and a similar effect was observed for chlorphenylamine $\left(10^{-6} \mathrm{M}\right)$, also an $\mathrm{H}_{1^{-}}$ antagonist (data not shown). Histamine $\left(10^{-5}\right.$ and $10^{-4} \mathrm{M}$ ) completely relaxed the precontracted arteries. Pretreatment with cimetidine $\left(3 \times 10^{-7}-\right.$ $10^{-5} \mathrm{M}$ ) inhibited the concentration-dependent relaxation induced by histamine $\left(10^{-7}-10^{-4} \mathrm{M}\right)$, and the highest cimetidine concentration $\left(10^{-5} \mathrm{M}\right)$ nearly abolished the responses completely ( $\mathrm{pD}_{2}, 5.99 \pm$ 0.15 ).

Precontracted arteries without endothelium ( $\mathrm{n}=$ 3) showed no histamine $\left(10^{-8}-10^{-5} \mathrm{M}\right)$ relaxation and a high concentration $\left(10^{-5} \mathrm{M}\right)$ caused little contraction (Fig. 8). Normal precontracted arteries relaxed in response to acetylcholine at $10^{-6} \mathrm{M}$, but the preparations without endothelium did not. However, the amplitude of contraction induced by $\mathrm{PGF}_{2 \alpha}\left(5 \times 10^{-6} \mathrm{M}\right)$ in the endothelium-free arteries was the same as in normal preparations (maximum contraction, $0.94 \pm 0.1 \mathrm{~g}$ for normal arteries and $1.02 \pm 0.2 \mathrm{~g}$ for rubbed arteries; $n=3$ ).

\section{Discussion}

Our experiments on human cerebral arteries 
demonstrated that histamine and 2-PEA (an $\mathrm{H}_{1}$ agonist) caused concentration-dependent contraction in the absence of active tension, while dimaprit (an $\mathrm{H}_{2}$-agonist) produced concentration-dependent vasorelaxation. The results of our earlier study were similar, i.e. histamine produced contraction in human cerebral arteries in the absence of active tension. ${ }^{26)}$ Tripelennamine (an $\mathrm{H}_{1}$-antagonist) inhibited histamine-induced contraction and cimetidine (an $\mathrm{H}_{2}$-antagonist) blocked dimaprit-induced relaxation.

Animal experiments using dog and cow showed that cerebral arteries have only contractile responses to histamine at various concentrations $\left(10^{-8}-10^{-4} \mathrm{M}\right)$ in the absence of active tension. ${ }^{7,17,25)}$ Histamine at lower concentrations caused vasodilation in cat cerebral arteries without active tension, while higher concentrations induced vasocontraction. ${ }^{20)}$ The vasodilation and vasocontraction were blocked by $\mathrm{H}_{2^{-}}$and $\mathrm{H}_{1}$-receptor antagonists, respectively. In vitro experiments showed that histamine and 2-PEA caused contraction of resting cat cerebral arteries, while impromidine (an $\mathrm{H}_{2}$-agonist) had no effect. ${ }^{10}$ )

In cat arteries precontracted with $\mathrm{PGF}_{2 x}$, histamine, 2-PEA and impromidine caused vascular relaxation which was reduced by the $\mathrm{H}_{2}$-antagonists. Edvinsson et al. ${ }^{10)}$ pointed out that the relaxation caused by histamine could only be seen when the vessel segments were first contracted in in vitro studies. The present experiments demonstrated that in $\mathrm{PGF}_{2 \alpha}$-precontracted arteries, histamine $\left(10^{-8}\right.$ $10^{-5} \mathrm{M}$ ) caused vasorelaxation, except at high concentrations $\left(10^{-4} \mathrm{M}\right)$ which caused contraction, although 2-PEA had no apparent effect. Dimaprit, however, caused relaxation, as in arteries without tone. Furthermore, histamine- and dimaprit-induced vasorelaxation was blocked by $\mathrm{H}_{2}$-antagonists in $\mathrm{PGF}_{2 \alpha}$-precontracted arteries. These results suggest that histamine-induced relaxation may be mediated by $\mathrm{H}_{2}$-receptors in human cerebral arteries, as in experimental animals. The vasomotor actions of histamine in human cerebral arteries are known to be generally somewhat similar to those in the corresponding arteries of experimental animals.

Rabbit cerebral arteries in vitro only show a contraction response to histamine, but the receptors have not been identified. ${ }^{5,8,21,28)}$ The contraction of pial arteries in vitro occurs via interaction of histamine with non-specific sites, since histamine-induced contraction was inhibited in a non-competitive manner by an $\mathrm{H}_{1}$-antagonist. ${ }^{9,10)}$ Similarly, these experiments on human cerebral arteries have shown that the vasocontraction and vasorelaxation induced by histamine are non-specific, since they are not blocked competitively by classical histamine receptor antagonists. The vasocontraction action of histamine may be partly indirect, in addition to the direct effect on histamine receptors. The present study also demonstrated that nifedipine completely blocked the contractile response to histamine. Thus, the activation of $\mathrm{H}_{1}$-receptors by histamine may increase $\mathrm{Ca}^{2+}$ influx through nifedipine-sensitive $\mathrm{Ca}^{2+}$ channels, resulting in the contraction of human cerebral arteries.

Histamine provokes the release of contraction-producing substances such as norepinephrine from the sympathetic innervation in human and cat cerebral arteries without tone in vitro. ${ }^{14,15)}$ Presumably an indirect adrenergic component may participate in the vasocontraction induced by histamine in human cerebral arteries. The present results suggest that this is most unlikely, since $\alpha$ - and $\beta$-adrenoceptorblocking agents had no effect on the vasomotor actions of histamine. Sercombe et al. ${ }^{23)}$ also suggested that an indirect adrenergic component does not participate in the vasocontraction action of histamine in rabbit cerebral arteries. The non-competitive inhibitory action of an $\mathrm{H}_{1}$-receptor antagonist against the contractile response to histamine may not involve $\mathrm{H}_{2}$-receptors, since this type of inhibition was observed in the presence of an $\mathrm{H}_{2}$-antagonist.

Our study raises the basic question of why the blocking action of a classical histamine antagonist on the histamine-induced contraction is not competitive in human cerebral arteries. Since the human cerebral arteries used in this experiment were obtained from autopsy of patients with systemic diseases, the non-specific type of histamine-induced contraction may be related to the pathological condition of the preparation.

Histamine may induce vasodilation by releasing the endothelium-derived relaxing factor (EDRF), as mediated by $\mathrm{H}_{1}$-receptors in rat thoracic aorta and mesenteric arteries, ${ }^{6,16,32)}$ and guinea-pig pulmonary arteries. ${ }^{1,22)}$ Nakane and $\mathrm{Chiba}^{18)}$ reported that endothelium removal did not affect the vascular response to histamine in canine coronary arteries. Toda $^{30)}$ showed that histamine-induced vasodilation was endothelium-dependent in monkey coronary arteries, but not in dog coronary arteries. Therefore, histamine-induced relaxation is not always endothelium-dependent, and differs between preparations and species of experimental animals. Sercombe et al. ${ }^{24)}$ demonstrated that $\mathrm{H}_{2}$-agonist-induced vasorelaxation in rabbit middle cerebral arteries was reduced in rubbed arteries and suggested that $\mathrm{H}_{2}$ dilatory receptors are situated on the endothelial cells. Our experiments on rubbed human arteries 
precontracted with $\mathrm{PGF}_{2 \alpha}\left(5 \times 10^{-7} \mathrm{M}\right)$ showed histamine did not induce relaxation, suggesting that histamine-induced relaxation is endothelium-dependent. However, $\mathrm{PGF}_{2 \alpha}$-induced contraction was the same in normal and rubbed cerebral arteries.

This study of human cerebral arteries demonstrated that histamine causes vasocontraction in the absence of active tension, but vasorelaxation in the presence of active tension. An $\mathrm{H}_{1}$-agonist produced contraction in the absence of active tension, but had no apparent effect in its presence. $\mathrm{An}_{2}$ agonist, however, consistently caused vasorelaxation in both the absence and presence of active tension. The vasocontracting and vasorelaxing effects of histamine in human cerebral arteries were inhibited by $\mathrm{H}_{1}$ - and $\mathrm{H}_{2}$-antagonists, respectively. Therefore, histamine-induced contraction and relaxation may be mediated mainly through $\mathrm{H}_{1}$ and $\mathrm{H}_{2}$ types of receptors, respectively. Histamine may also induce vasodilation by releasing EDRF, mediated by $\mathrm{H}_{2}-$ receptors, but this requires direct confirmation. The possible localization and functional importance of histamine receptors in cerebral arteries still require further evaluation.

\section{References}

1) Abacioglu N, Ercan ZS, Kanzik I, Zengil H, Deniryürek T, Türker RK: Endothelium-dependent relaxing effect of histamine on the isolated guinea-pig main pulmonary artery strips. Agents Actions 22: $30-$ 35, 1987

2) Allen GS, Henderson LM, Chou SN, French LA: Cerebral arterial spasm. Part 1: In vitro contractile activity of vasoactive agents on canine basilar and middle cerebral arteries. $J$ Neurosurg 40: 433-441, 1974

3) Anderson WD, Kubicek WG: Effects of betahistine $\mathrm{HCl}$, nicotinic acid and histamine on basilar blood flow in anesthetized dogs. Stroke 2: 409-415, 1971

4) Arunlakshana O, Schild HO: Some quantitative uses of drug antagonists. Brit $J$ Pharmacol 14: 48-58, 1958

5) Bevan JA, Duckles SP, Lee TJ-F: Histamine potentiation of nerve and drug-induced responses of a rabbit cerebral artery. Circ Res 36: 647-653, 1975

6) Carrier OG, White RE, Kirby ML: Histamine-induced relaxation of rat aorta: Importance of $\mathrm{H}_{1}$ receptor and vascular endothelium. Blood Vessels 21: $180-$ 183,1984

7) Cheng JB, Shibata S: Reactivity of isolated bovine cerebral arteries to biogenic amines. Gen Pharmacol 9: 189-193, 1978

8) Duckles SP, Bevan JA: Responses of small rabbit pial arteries in vitro. Blood Vessels 16: 80-86, 1979

9) Edvinsson BM, Owman $\mathrm{CH}$ : A pharmacological comparison of histamine receptors in isolated ex- tracranial and intracranial arteries in vitro. Neurology (Minneap) 25: 271-276, 1975

10) Edvinsson L, Gross PM, Mohamed A: Characterization of histamine receptors in cat cerebral arteries in vitro and in situ. J Pharmacol Exp Ther 225: 168175,1983

11) Gross PM: Histamine $\mathrm{H}_{1^{-}}$and $\mathrm{H}_{2}$-receptors are differentially and spatially distributed in cerebral vessels. J Cereb Blood Flow Metab 1: 441-446, 1981

12) Gross PM: Histaminergic dilation of resistance vessels in the brain, in Vanhoutte PM, Banter SF (eds): 3rd International Symposium Mechanisms of Vasodilation. Basel, Karger, 1984, pp 138-148

13) Kuschinsky $W$, Wahl $M$ : In vivo evaluation of histamine receptors at pial arteries. Acta Neurol Scand [Suppl] 64: 382-383, 1977

14) Marco EJ, Balfagon G, Conde MV: Indirect adrenergic effect of histamine in human cerebral arteries: Influence of post mortem period. J Pharm Pharmacol 36: 253-255, 1984

15) Marco EJ, Balfagon G, Marin J, Gomez B, Luch S: Indirect adrenergic effect of histamine in cat cerebral arteries. Naunyn Schmiedebergs Arch Pharmacol 312: 239-243, 1980

16) Moritoki $\mathrm{H}$, Hosoki $\mathrm{E}$, Ishida $\mathrm{Y}$ : Age-related decrease in endothelium-dependent dilator response to histamine in rat mesenteric artery. Eur $J$ Pharmacol 126: 61-67, 1986

17) Muramatsu L, Fujiwara M, Osumi $Y$, Shibata S: Vasoconstrictor and dilator actions of nicotine and electrical stimulation on isolated dog cerebral arteries. Blood Vessels 15: 1-10, 1978

18) Nakane $T$, Chiba $S$ : Characteristics of histamine receptors in the isolated and perfused canine coronary arteries. Arch Int Pharmacodyn Ther 290: 92103,1987

19) Nielsen $\mathrm{KC}$, Owman C: Contractile response to amine receptor mechanism in isolated middle cerebral artery of the cat. Brain Res 27: 33-42, 1971

20) Owman C, Edvinsson L, Nielsen KC: Automatic neuroreceptor mechanisms in brain vessels. Blood Vessels 11: 2-31, 1974

21) Politoff A, Marcri F: Pharmacologic differences between isolated perfused arteries of the choroid plexus and of the brain parenchyma. Int $J$ Neuropharmacol 5: $155-162,1966$

22) Satoh H, Inui J: Endothelial cell-dependent relaxation and contraction induced by histamine in the isolated guinea-pig pulmonary artery. Eur $J$ Pharmacol 97: 321-324, 1984

23) Sercombe R, Verrecchia C, Oudart N, Dimitriadou V, Seylaz J: Pial artery responses to norepinephrine potentiated by endothelium removal. $J$ Cereb Blood Flow Metab 5: 312-317, 1985

24) Sercombe R, Verrecchia C, Philipson V, Oudart N, Dimitriadou V, Bouchaud C, Seylaz J: Histamine-induced constriction and dilatation of rabbit middle cerebral arteries in vitro: Role of the endothelium. Blood Vessels 23: 137-153, 1986 
25) Shibata $S$ : The effect of drugs on the automatic neuroeffector system of cerebral arteries, in Carrier $\mathrm{O}$ $\mathrm{Jr}$, Shibata S (eds): Factors Influencing Vascular Reactivity. New York, Igaku-Shoin, 1977, pp 132155

26) Shibata S, Cheng JB, Murakami W: Reactivity of isolated human cerebral arteries to biogenic amines. Blood Vessels 14: 356-365, 1975

27) Sokoloff L: The action of drugs on the cerebral circulation. Pharmacol Rev 11: 1-85, 1959

28) Sundt TM Jr, Winkelmann RK: Humoral responses of smooth muscle from rabbit subarachnoid artery compared to kidney, mesentery, lung, heart and skin vascular smooth muscle. Stroke 3: 717-725, 1972

29) Tindall GT, Greenfield JC: The effects of intraarterial histamine on blood flow in the internal and external carotid artery of man. Stroke 4: 46-49, 1973

30) Toda N: Mechanism of histamine-induced relaxation in isolated monkey coronary arteries. I Pharmacol
Exp Ther 239: 529-535, 1986

31) Urquilia PR, Marco EJ, Salvador L: Pharmacological receptors of the cerebral arteries of the goat. Blood Vessels 12: 53-67, 1975

32) Van de Voorde J, Leusen I: Role of endothelium in the vasodilator response of rat thoracic aorta to histamine. Eur J Pharmacol 87: 113-120, 1983

33) Wahl M, Kuschinsky W: The dilating effect of histamine on pial arteries of cats and its mediation by $\mathrm{H}_{2}$-receptors. Circ Res 44: 161-165, 1979

34) Watters JW: The effects of bradykinin and histamine on cerebral arteries of monkeys. Radiology 98: 299303,1971

Address reprint requests to: T. Takagi, M.D., Department of Neurosurgery, Nagoya City Higashi General Hospital, 1-2-23 Wakamizu, Chikusa-ku, Nagoya 464, Japan. 